\title{
Labor Productivity Differences in China 1987-1997: An Interregional Decomposition Analysis
}

\author{
Ling Yang and Michael L. Lahr ${ }^{*}$
}

\begin{abstract}
The literature on regional disparities in China is both broad and deep. Nonetheless, much of its focus has been on the effects of trade liberalization and national policies toward investment in interior provinces. Few pieces have examined whether the disparities might simply be due to differences in industry mix, final demand, or even interregional trade. Using two newly published multiregional input-output tables and disaggregated employment data, we decompose change in labor productivity growth for seven regions of China between 1987 and 1997 into five partial effects - changes in value added coefficients, direct labor requirements, aggregate production mix, interregional trade, and final demand. Subsequently we summarize the contributions to labor productivity of the different factors at the regional level. In this way, we present a new perspective on recent causes of China's interregional disparity in GDP per capita.
\end{abstract}

Keywords: Decomposition, input-output analysis, productivity, regional disparity, China

JEL classification: C67, O40, R15

\section{INTRODUCTION}

As GDP has soared, interregional income disparity has become a major policy challenge in China due to increasing concerns about social stability (Démurger, 2001). From 1952 to 2007, China's GDP grew at an annual average rate of nearly 8.0 percent and even more rapidly during the last three decades-9.7 percent annually from 1978 to 2007. Along with the rapid growth, China's regional disparity as reflected in labor productivity also attracts much attention. On the east coast, Shanghai's 2007 labor productivity was 139,049 RMB per worker-more than ten times that of Guizhou province, which lies far to the west and had an annual productivity in 2007 of 12,010 RMB per worker. ${ }^{1}$

Some of the regional disparity seems to be a result of national economic reforms implemented since 1978. Preferential policies for coastal provinces were an initial element of the reformation programs designed to jumpstart China's trade with the world. During the 1980s, the cities of Shenzhen, Zhuhai, Shantou, and Xiamen were designated, along with Hainan province, as special economic zones. Dalian, Guangzhou, Shanghai and 14 other cities were designated open coastal cities. The policies provided for tax abatements, infrastructure projects, and preferential foreign exchange. The overall preferential policy regime was designed to attract

\footnotetext{
* Yang is a $\mathrm{PhD}$ candidate at the School of Economics and Finance, Xi'an Jiaotong University, China. Lahr is an Associate Research Professor with the Center for Urban Policy Research, Edward J. Bloustein School of Planning and Public Policy, Rutgers, The State University of New Jersey.

Contact Author: Michael L. Lahr, CUPR, Rutgers University, 33 Livingston Avenue, New Brunswick, NJ, 08901-1982. E-mail: lahr@rutgers.edu.

${ }^{1}$ Calculated using data from 2008 China Statistical Yearbook. 
foreign investment and business - to develop these places as "growth poles" for China's economy. Whether or not these policies actually caused the subsequent growth remains unclear, but particularly strong growth ensued in the coastal economies nonetheless.

Of course, the strong growth in these areas also exacerbated pre-existing regional income disparities. In response to the deepening interregional income disparities, China's national government has since proposed a number of specially designed development strategies tailored to each region's history, culture, and economic conditions. In 1999, for example, the government proposed the West Development Strategy to increase capital availability in its westernmost provinces with a special interest in enhancing opportunities for foreign trade for these provinces: it included measures to improve the financial environment for infrastructure, human capital, and technology production. In 2002, China proposed a policy called "Revitalization of the Traditional Industrial Bases" for Northeast China. It emphasized institutional innovation in a region that was a national leader prior to the reforms, and hence focused on restructuring stateowned enterprises, upgrading industry structure and promoting modern tertiary industry, creating jobs for the unemployed and providing social security, promoting sustainable development of resource-based cities, developing modern agriculture, and so on. In 2004, Central China Rising was proposed. The policies were a mix designed to reinvigorate the region's traditional industrial base (and thus largely followed those policies devised for the Northeast) and to get Central China's less-developed areas better aligned with the nation's overall goal of being more engaged in international trade (and thus also included policies previously applied to the West). The policies were supposed to help improve productivity in the nation's "breadbasket," energy resource base, and equipment manufacturing centers; they were also implemented with the hope that they would help to expand high-tech industry into Central China.

It remains unclear exactly what set of dynamics instigated China's large interregional productivity inequality gaps prior to enactment of the aforementioned policy regime of the current century. Literature investigating the causes of interregional disparity in China has cited many possibilities. Those cited have included differences in infrastructure development like transportation and telecommunications networks (Démurger, 2001); the source, size and sectoral allocation of fixed investment (Wei, 2000); the speed in the adoption of new technology; level of human capital stock (Liu and Li 2006); the accessibility of foreign direct investment and international trade (Sun and Parikh, 2001; Wei and Wu, 2001); labor market distortions like the Hukou system, which impedes labor mobility from rural to urban areas (Cai, Wang, and Du, 2002); and province-specific public policy strategies (Lin and Liu, 2008; Kanbur and Zhang, 2005; Démurger et al., 2002a,b; Yang, 2002). But none of these seems to account for more than a small measure of the interregional differences.

Few pieces have examined whether the disparities and any convergence across them might simply be due to differences and changes in industry mix, in interregional trade, or even in the composition of final demand. Li and Haynes (2008) use the shift-share method to analyze China's regional disparity at province level from an industry structure point of view. Still, the fact that China's industries are interdependent as expressed in input-output (I-O) parlance remains nearly completely overlooked. As a result, we take a different approach in our analysis of Chinese interregional productivity; we use the country's 1987 and 1997 multiregional inputoutput (MRIO) tables with seven regions, disaggregated employment data, and a decomposition approach introduced by Dietzenbacher, Hoehn, and Los (2000). This approach decomposes productivity into five partial effects - changes in value added coefficients, direct labor 
requirements, aggregate production mix, technology change, interregional trade, and final demand. Subsequently we summarize the contributions to labor productivity of the different factors at the regional level.

The paper is organized as follows. Section 2 outlines our research approach. Section 3 is a general description of the data used in this paper. In Section 4, we analyze the results of our decomposition. A final section concludes the paper.

\section{RESEARCH APPROACH}

There are many ways to examine the likely causes of productivity change. We are particularly interested in finding out the many ways in which China's economic reforms affected interregional income disparity. Was technological change a major player? What about changes in interregional trade? Perhaps the disparity was enhanced by the degree to which different sectors managed to discover ways outside of technological change to save on labor costs. How much did margin-reducing pressures of interregional trade affect per capita GDP across regions? Were most of the disparities introduced via trade-important manufacturing or did other sectors play a role? After considering the sorts of issues that we were interested in answering, it was decided that the multiplicative decomposition method introduced by Dietzenbacher, Hoen, and Los (2000) would be best suited for our purposes.

The following presents Dietzenbacher, Hoen, and Los's (2000) approach as we adopted it. $^{2}$ Let $N$ be the number of industries in each region and $C$ be the number of regions. The other definitions are as follows:

v: aggregate value added (scalar);

$l$ : aggregate labor inputs (scalar);

$\pi$ : aggregate labor productivity $(v / l)$ (scalar);

A: matrix with input coefficients $(N C \times N C$ matrix $)$, with typical element $\alpha_{i j}^{r s}$ denoting the input of product $i$ from region $r$ per unit of output in industry $j$ in region $s$;

\section{$\mathbf{L}$ : Leontief-inverse $(N C \times N C$ matrix $), \mathbf{L} \equiv(\mathbf{I}-\mathbf{A})^{-1}$;}

$\mathbf{x}$ : vector with $\chi_{i}^{r}$ denotes the gross output level of industry $i$ in region $r(N C \times 1$ vector);

f: vector with element $f_{i}^{r}$ denotes the final demand for output of industry $i$ in region $r(N C \times 1$ vector), which include consumption, gross fixed capital formation, changes in inventories, export and import;

$\lambda$ : vector with elements $\lambda_{i}^{r}$ giving the use of labor per unit of gross output in industry $i$ in region $r$ $(N C \times 1$ vector $)$;

\footnotetext{
${ }^{2}$ Dietzenbacher, Hoen, and Los (2000) used six factors - one more than we do here. This is because they had the luxury of using data showing how interregional trade was used to meet final demand. One of the Chinese MRIO tables does not permit such an analysis. In addition, the same Chinese MRIO table lacks details on the disposition of final demand.
} 
$\boldsymbol{\mu}$ : vector with elements $\mu_{i}^{r}$ giving the value added per unit of gross output in industry $i$ in region $r(N C \times 1$ vector $)$;

$\mathbf{A}^{*}$ : matrix constructed by stacking $C$ identical $N \times N C$ matrices of aggregate intermediate inputs per unit of gross output by industry by region $(N C \times N C$ matrix $), \forall r:\left[\alpha^{*}\right]_{i j}^{r s}=\sum_{r=1}^{C} \alpha_{i j}^{r s}$;

$\mathbf{T}^{\mathbf{A}}$ : matrix of intermediate trade coefficients, representing the shares of each region in aggregate inputs, by input by industry by region $(N C \times N C$ matrix $),\left[t^{\mathbf{A}}\right]_{i j}^{r s}=\alpha_{i j}^{r s} /\left[\alpha^{*}\right]_{i j}^{r s}$, note that $\sum_{r}\left[t^{\mathbf{A}}\right]_{i j}^{r s}=1$;

It follows that

$$
\begin{aligned}
& \nu=\boldsymbol{\mu}^{\prime} \mathbf{x} \text { and } l=\lambda^{\prime} \mathbf{x} \\
& \mathbf{x}=\mathbf{A} \mathbf{x}+\mathbf{f}=(\mathbf{I}-\mathbf{A})^{-1} \mathbf{f}=\mathbf{L f},
\end{aligned}
$$

and thus

$$
\nu=\mu^{\prime} \mathbf{L f} \text { and } l=\lambda^{\prime} \mathbf{L f}
$$

for which primes indicate transposed vectors. The aggregate labor productivity change can be written as:

$$
\begin{aligned}
& \frac{\pi_{1}}{\pi_{0}}=\frac{v_{1}}{v_{0}} \div \frac{l_{1}}{l_{0}}=\frac{\boldsymbol{\mu}_{1}^{\prime} \mathbf{L}_{1} \mathbf{f}_{1}}{\boldsymbol{\mu}_{0}^{\prime} \mathbf{L}_{0} \mathbf{f}_{0}} \div \frac{\lambda_{1}^{\prime} \mathbf{L}_{1} \mathbf{f}_{1}}{\lambda_{0}^{\prime} \mathbf{L}_{0} \mathbf{f}_{0}} \\
& =\left(\frac{\boldsymbol{\mu}_{1}^{\prime} \mathbf{L}_{1} \mathbf{f}_{1}}{\boldsymbol{\mu}_{0}^{\prime} \mathbf{L}_{1} \mathbf{f}_{1}}\right)\left(\frac{\lambda_{0}^{\prime} \mathbf{L}_{1} \mathbf{f}_{1}}{\lambda_{1}^{\prime} \mathbf{L}_{1} \mathbf{f}_{1}}\right)\left(\frac{\boldsymbol{\mu}_{0}^{\prime} \mathbf{L}_{1} \mathbf{f}_{1}}{\boldsymbol{\mu}_{0}^{\prime} \mathbf{L}_{0} \mathbf{f}_{1}} \times \frac{\lambda_{0}^{\prime} \mathbf{L}_{0} \mathbf{f}_{1}}{\lambda_{0}^{\prime} \mathbf{L}_{1} \mathbf{f}_{1}}\right)\left(\frac{\boldsymbol{\mu}_{0}^{\prime} \mathbf{L}_{0} \mathbf{f}_{1}}{\boldsymbol{\mu}_{0}^{\prime} \mathbf{L}_{0} \mathbf{f}_{0}} \times \frac{\lambda_{0}^{\prime} \mathbf{L}_{0} \mathbf{f}_{0}}{\lambda_{0}^{\prime} \mathbf{L}_{0} \mathbf{f}_{1}}\right)
\end{aligned}
$$

By using $\mathrm{L}=\left(\mathrm{I}-\mathrm{A}^{*} \circ \mathrm{T}^{\mathrm{A}}\right)^{-1}(\circ$ represents elementwise multiplication), we can get the final decomposition of labor productivity change:

$$
\frac{\pi_{1}}{\pi_{0}}=(1.1) \times(1.2) \times(1.3) \times(1.4) \times(1.5)
$$

with

$$
\begin{aligned}
& (1.1)=\left(\frac{\boldsymbol{\mu}_{1}^{\prime} \mathbf{L}_{1} \mathbf{f}_{1}}{\boldsymbol{\mu}_{0}^{\prime} \mathbf{L}_{1} \mathbf{f}_{1}}\right) \\
& (1.2)=\left(\frac{\lambda_{0}^{\prime} \mathbf{L}_{1} \mathbf{f}_{1}}{\lambda_{1}^{\prime} \mathbf{L}_{1} \mathbf{f}_{1}}\right) \\
& (1.3)=\left\{\frac{\boldsymbol{\mu}_{0}^{\prime}\left[\mathbf{I}-\left(\mathbf{A}_{1}^{*} \circ \mathbf{T}_{1}^{\mathbf{A}}\right)\right]^{-1} \mathbf{f}_{\mathbf{1}}}{\boldsymbol{\mu}_{0}^{\prime}\left[\mathbf{I}-\left(\mathbf{A}_{0}^{*} \circ \mathbf{T}_{1}^{\mathbf{A}}\right)\right]^{-1} \mathbf{f}_{1}} \times \frac{\lambda_{0}^{\prime}\left[\mathbf{I}-\left(\mathbf{A}_{0}^{*} \circ \mathbf{T}_{1}^{\mathbf{A}}\right)\right]^{-1} \mathbf{f}_{1}}{\lambda_{0}^{\prime}\left[\mathbf{I}-\left(\mathbf{A}_{1}^{*} \circ \mathbf{T}_{1}^{\mathbf{A}}\right)\right]^{-1} \mathbf{f}_{1}}\right\}
\end{aligned}
$$

Southern Regional Science Association 2010. 


$$
\begin{aligned}
& (1.4)=\left\{\frac{\boldsymbol{\mu}_{0}^{\prime}\left[\mathbf{I}-\left(\mathbf{A}_{0}^{*} \circ \mathbf{T}_{1}^{\mathbf{A}}\right)\right]^{-1} \mathbf{f}_{1}}{\boldsymbol{\mu}_{0}^{\prime}\left[\mathbf{I}-\left(\mathbf{A}_{0}^{*} \circ \mathbf{T}_{0}^{\mathbf{A}}\right)\right]^{-1} \mathbf{f}_{1}} \times \frac{\boldsymbol{\lambda}_{\mathbf{0}}^{\prime}\left[\mathbf{I}-\left(\mathbf{A}_{0}^{*} \circ \mathbf{T}_{0}^{\mathbf{A}}\right)\right]^{-1} \mathbf{f}_{1}}{\lambda_{\mathbf{0}}^{\prime}\left[\mathbf{I}-\left(\mathbf{A}_{0}^{*} \circ \mathbf{T}_{1}^{\mathbf{A}}\right)\right]^{-1} \mathbf{f}_{1}}\right\} \\
& (1.5)=\left(\frac{\boldsymbol{\mu}_{0}^{\prime} \mathbf{L}_{0} \mathbf{f}_{1}}{\boldsymbol{\mu}_{0}^{\prime} \mathbf{L}_{0} \mathbf{f}_{0}} \times \frac{\lambda_{0}^{\prime} \mathbf{L}_{0} \mathbf{f}_{0}}{\lambda_{0}^{\prime} \mathbf{L}_{0} \mathbf{f}_{1}}\right)
\end{aligned}
$$

in which indices are time indicators, $\mathbf{0}$ denoting 1987 and $\mathbf{1}$ denoting 1997.

Equation (1.1) represents the productivity effects of changes in the value added figures per unit of gross output by industry; Equation (1.2) represents the effects of changed labor requirement per unit of gross output by industry; Equation (1.3) represents the effects of changes in the inter-industry structure (due to technological change, factor substitution, changing output compositions within industries, etc.); Equation (1.4) is the productivity effects of changed structures with respect to commodities and services used as intermediate inputs; Equation (1.5) is the effects of changes in the final demand.

There is an obvious index-number problem here, so the other polar decomposition is expressed as follows:

$$
\frac{\pi_{1}}{\pi_{0}}=(2.1) \times(2.2) \times(2.3) \times(2.4) \times(2.5)
$$

with

$$
\begin{aligned}
& (2.1)=\left(\frac{\boldsymbol{\mu}_{1}^{\prime} \mathbf{L}_{0} \mathbf{f}_{0}}{\boldsymbol{\mu}_{0}^{\prime} \mathbf{L}_{0} \mathbf{f}_{0}}\right) \\
& (2.2)=\left(\frac{\lambda_{0}^{\prime} \mathbf{L}_{0} \mathbf{f}_{0}}{\lambda_{1}^{\prime} \mathbf{L}_{0} \mathbf{f}_{0}}\right) \\
& (2.3)=\left\{\frac{\boldsymbol{\mu}_{1}^{\prime}\left[\mathbf{I}-\left(\mathbf{A}_{1}^{*} \circ \mathbf{T}_{0}^{\mathbf{A}}\right)\right]^{-1} \mathbf{f}_{0}}{\boldsymbol{\mu}_{1}^{\prime}\left[\mathbf{I}-\left(\mathbf{A}_{0}^{*} \circ \mathbf{T}_{0}^{\mathbf{A}}\right)\right]^{-1} \mathbf{f}_{0}} \times \frac{\lambda_{1}^{\prime}\left[\mathbf{I}-\left(\mathbf{A}_{0}^{*} \circ \mathbf{T}_{0}^{\mathbf{A}}\right)\right]^{-1} \mathbf{f}_{0}}{\lambda_{1}^{\prime}\left[\mathbf{I}-\left(\mathbf{A}_{1}^{*} \circ \mathbf{T}_{0}^{\mathbf{A}}\right)\right]^{-1} \mathbf{f}_{0}}\right\} \\
& (2.4)=\left\{\frac{\boldsymbol{\mu}_{1}^{\prime}\left[\mathbf{I}-\left(\mathbf{A}_{1}^{*} \circ \mathbf{T}_{1}^{\mathbf{A}}\right)\right]^{-1} \mathbf{f}_{0}}{\boldsymbol{\mu}_{1}^{\prime}\left[\mathbf{I}-\left(\mathbf{A}_{1}^{*} \circ \mathbf{T}_{0}^{\mathbf{A}}\right)\right]^{-1} \mathbf{f}_{0}} \times \frac{\lambda_{1}^{\prime}\left[\mathbf{I}-\left(\mathbf{A}_{1}^{*} \circ \mathbf{T}_{0}^{\mathbf{A}}\right)\right]^{-1} \mathbf{f}_{0}}{\lambda_{1}^{\prime}\left[\mathbf{I}-\left(\mathbf{A}_{1}^{*} \circ \mathbf{T}_{1}^{\mathbf{A}}\right)\right]^{-1} \mathbf{f}_{0}}\right\} \\
& (2.5)=\left(\frac{\boldsymbol{\mu}_{1}^{\prime} \mathbf{L}_{1} \mathbf{f}_{1}}{\boldsymbol{\mu}_{1}^{\prime} \mathbf{L}_{1} \mathbf{f}_{0}} \times \frac{\lambda_{1}^{\prime} \mathbf{L}_{1} \mathbf{f}_{0}}{\lambda_{1}^{\prime} \mathbf{L}_{1} \mathbf{f}_{1}}\right)
\end{aligned}
$$

When we decompose for each region and industry, we replace the vectors $\boldsymbol{\lambda}$ and $\boldsymbol{\mu}$ in Equations (1) and (2) with diagonal matrices with the same elements on the main diagonal and zeroes elsewhere, and pre-multiply all numerators and denominators with $(1 \times N C)$ aggregation vectors, one for each region or industry. 


\section{DATA}

The data used in our paper are multiregional input-output (MRIO) tables of China for 1987 (Ichimura and Wang, 2003) and 1997 (China's State Information Center, 2005). MRIO tables are complex: they capture the interregional linkages as well as the aspects of production. That is, the economic system is described in terms of interdependent industries and interrelated regions. Few countries have official MRIO tables because of the difficulty in generating interregional flow data as well as official survey-based regional tables. Unfortunately, China's two MRIO tables are not perfectly consistent. The main source of data for the $1987 \mathrm{MRIO}$ is a set of 30 regional I-O tables produced by the country's various provinces, autonomous regions, and municipalities. The MRIO table for 1997 was produced using hybrid techniques with interregional trade flows based on survey data. ${ }^{3}$ Thus we were forced to undertake certain procedures to make them comparable.

Prior to the present paper, Meng and Qu (2007) used the two Chinese MRIO tables to decompose gross output growth, rather than labor productivity change, and focused upon the nature of interregional relationships. They highlighted the performance of China's industrial and regional development policies on the magnitudes of interregional spillovers and feedbacks, which is a different focus from that we present here. Hioki and Okamoto (2009) and Hioki, Hewings, and Okamoto (2009) also used the tables, but applied a qualitative input-output approach to identify changes in the largest spatial linkages among China's main regions since undertaking reforms. In sum, while the two tables have some compatibility problems, the efforts of these two research groups showed that the worst of them can be overcome in a satisfactory manner.

To make some limitations to our study clear, we start by explaining how we dealt with differences in region definitions across the two MRIO tables. There were seven regions altogether in 1987 and eight in 1997 (see Figure 1). Thus, in the 1997 accounts we aggregated the North Municipalities with North Coast, the result of which conformed to the North China region in the geography of the 1987 MRIO accounts (see Table 1 for details). Another change between 1987 and 1997 in Chinese political geography was that, in 1987, Chongqing was included within Sichuan province, while in 1997 it was a separate municipality directly under the central government. Fortunately, within the I-O accounts this was not an issue since both were assigned to the Southwest region in both years. But a discrepancy does arise in the assignment of Inner Mongolia, which belonged to North China in 1987 but to the Northwest in 1997. Unfortunately, we have no way to correct for this problem since more detailed region classifications are lacking. We proceeded as if this was not an issue since Inner Mongolia is economically rather small. ${ }^{4}$ Of course, we acknowledge that it could produce some bias in our results.

\footnotetext{
${ }^{3}$ There are other critical differences in the accounting schemes that make interpretation of decomposition results difficult regardless of the technique that is applied. For example, the 1997 table includes interregional trade of final demand, but the 1987 table does not. Moreover, the 1987 MRIO table is influenced by the MPS statistical system: thus, welfare is included in value added accounts and social consumption in final demand accounts. Intermediate deliveries among regions in the service sector are reported in 1987 MRIO table while service demands are assumed to be met by local supply only in the 1997 MRIO table.

${ }^{4}$ We found that Inner Mongolia comprised 23.5 percent of the Northwest's GDP in 1997 and 8 percent of North China's GNI in 1987. Thus the shift in Inner Mongolia's economic alliance is more likely to lead to bias in the analysis of the Northwest than it is in our analysis of North China. However, the bias is not expected to be large since much of the difference made by the different scheme of regional (sectoral) aggregation is averaged out when we work with input-output coefficients (Hioki and Okamoto, 2009).
}

Southern Regional Science Association 2010. 
Table 1. China MRIO Region Definitions, 1987 and 1997

\begin{tabular}{ll|ll}
\hline \hline \multicolumn{2}{l|}{$\mathbf{1 9 8 7}$} & \multicolumn{1}{l}{$\mathbf{1 9 9 7}$} \\
$\begin{array}{l}\text { Region } \\
\text { (Abbreviation) }\end{array}$ & Provinces & $\begin{array}{l}\text { Region } \\
\text { (Abbreviation) }\end{array}$ & Provinces \\
\hline North East (NE) & $\begin{array}{l}\text { Liaoning, } \\
\text { Heilongjiang }\end{array}$ & Jilin, & Liaoning, Jilin, Heilongjiang \\
& $\begin{array}{l}\text { Beijing, Tianjin } \\
\text { Hebei, Shandong } \\
\text { Inner Mongolia }\end{array}$ & $\begin{array}{l}\text { North Municipalities } \\
\text { North Coast (NC) }\end{array}$ & $\begin{array}{l}\text { Beijing, Tianjin } \\
\text { Hebei, Shandong }\end{array}$ \\
\hline East China (EC) & Shanghai, Jiangsu, Zhejiang & East China (EC) & Shanghai, Jiangsu, Zhejiang \\
\hline South China (SC) & Guangdong, Fujian, Hainan & South Coast (SC) & Guangdong, Fujian, Hainan \\
\hline Central China (CC) & $\begin{array}{l}\text { Shanxi, Henan, Anhui } \\
\text { Hubei, Hunan, Jiangxi }\end{array}$ & Central China (CC) & $\begin{array}{l}\text { Shanxi, Henan, Anhui } \\
\text { Hubei, Hunan, Jiangxi }\end{array}$ \\
\hline North West (NW) & $\begin{array}{l}\text { Shaanxi, Gansu, Ningxia } \\
\text { Qinghai, Xinjiang }\end{array}$ & Northwest (NW) & $\begin{array}{l}\text { Shaanxi, Gansu, Ningxia } \\
\text { Qinghai, Xinjiang } \\
\text { Inner Mongolia }\end{array}$ \\
\hline \hline & $\begin{array}{l}\text { Sichuan, Guizhou, Yunnan } \\
\text { Guangxi, Tibet }\end{array}$ & Southwest (SW) & $\begin{array}{l}\text { Sichuan, Chongqing, Guizhou, } \\
\text { Yunnan, Guangxi, Tibet }\end{array}$ \\
\hline
\end{tabular}

Figure 1. The Seven MRIO Regions of China 1997

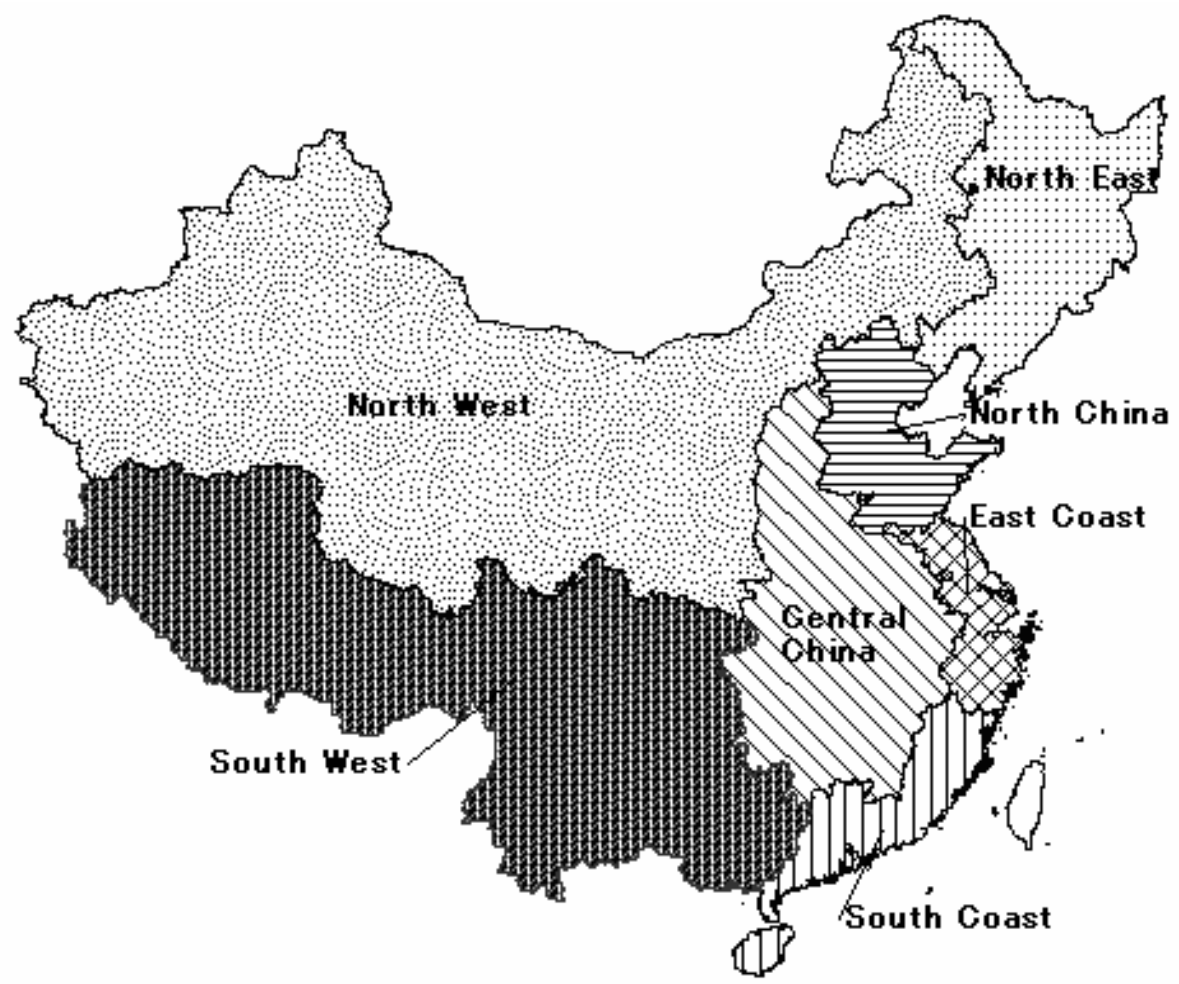

Source: Hioki and Okamoto (2009) 
Unfortunately, we could only obtain labor data for five more aggregated industries by region over the period of study. Therefore, to preserve as much information as possible, we first aggregate all the vectors or matrices (except those with labor input involved) into seven sectors, continue calculation, and then aggregate them into five sectors when confronted with labor input vectors.

Table 2 compares characteristics of the 1987 and 1997 MRIO tables and the employment data we used for each year. Note that aside from labor data issues, there were also some other industry-based accounting issues that could not be avoided. The postal and telecommunication industries are in the Service sector in the 1997 table but in the Trade and Transportation sector in 1987; eating and drinking establishments are included in the Service sector in the 1997 table but in the Trade and Transportation sector in the 1987 table.

Referring to the construction of the trade coefficient matrices $\mathbf{T}^{\mathbf{A}}$, we assigned the trade coefficient to be zero when its total use was zero; when the total use was zero in one year but positive in the other, we assigned to the zero-valued entry the corresponding trade coefficient for the year in which it was nonzero. This forces labor productivity in these situations to be attributed to changes in the structure of inputs and not to changes in trade when all other values remain equal.

Since I-O tables are in value terms and both MRIO tables are in nominal prices, to eliminate price effects we had to either inflate the values in the 1987 table or deflate those in the 1997 table. We opted to deflate the 1997 input-output table to make its values consistent with those in 1987. This also enabled us to preserve information from the original data, because there are 17 industries in 1997 and 9 industries in 1987 and usually aggregation after deflation is preferred. The drawback to this is that we did not use data in prices to which the reader can more readily relate, i.e., in 1997 prices.

We used RAS to deflate the 1997 MRIO table. According to Dietzenbacher and Hoen (1998), RAS is commonly used to deflate I-O tables, at least in academic literature. Price indices from 1987 to 1997 were available only at the national level for the 17 industries in the 1997 MRIO: we used them as deflators since regional equivalents were unavailable. Then we aggregated both the 17 industries in 1997 and the 9 industries in 1987 into the 7 industries we used in the ensuing empirical analysis. The Appendix explains which deflators we used and how we applied them for each industry.

\section{EMPIRICAL ANALYSIS}

\subsection{Descriptive statistics}

Labor productivity is value added per unit of labor input. We divided the value added by the corresponding employment in 1987 and 1997, respectively. The employment data we used measures the total persons employed within each region's sectors during the corresponding year.

Tables 3 and 4 show general information on labor productivity for both sectors and regions. Table 3 focuses on sectors, and Table 4 on regions. Figure 2 shows sectoral growth rates for each region. Table 3 shows that labor productivity levels were quite different across sectors and that big differences existed among regions, even for the same industry.

Of the sectors we examine, Manufacturing had the highest labor productivity in both 1987 and 1997. It was followed by Trade and Transportation, Service, Construction, and Agriculture in 1987. In 1997, labor productivity in Service, Construction, and Trade and 
Table 2. Comparison of industries for MRIO1987 and MRIO 1997 and employment data

\begin{tabular}{|c|c|c|c|c|}
\hline Industries(Abbreviation) & $\begin{array}{l}9 \text { industries IRIO } 1987 \\
\text { (Ichimura and Wang, 2003) }\end{array}$ & $\begin{array}{l}17 \text { industries MRIO } 1997 \\
(\mathrm{SIC}, 2005)\end{array}$ & $\begin{array}{l}13 \text { industries } \\
\text { Employment in } 1987 \\
\text { (China Statistical Yearbook, 1988) } \\
\end{array}$ & $\begin{array}{l}16 \text { industries } \\
\text { Employment in } 1997 \\
\text { (China Statistical Yearbook, 1998) }\end{array}$ \\
\hline 1. Agriculture (AGR) & 1. Agriculture & 1. Agriculture & $\begin{array}{l}\text { 1. Farming, forestry, animal husbandry } \\
\text { and fishery, water conservancy }\end{array}$ & $\begin{array}{l}\text { 1. Farming, forestry, animal husbandry } \\
\text { and fishery }\end{array}$ \\
\hline $\begin{array}{l}\text { 2. Mining, light industry, } \\
\text { heavy industry and supply of } \\
\text { electricity, gas and water } \\
\text { (MAN) }\end{array}$ & $\begin{array}{l}\text { 2. Mining and processing } \\
\text { 3. Light industry } \\
\text { 4. Energy industry } \\
\text { 5.Heavy industry and } \\
\text { chemical industry }\end{array}$ & $\begin{array}{l}\text { 2. Mining } \\
\text { 3. Food Products } \\
\text { 4. Textile and wearing apparel } \\
\text { 5. Wooden products } \\
\text { 6. Paper and printing } \\
\text { 7. Chemical products } \\
\text { 8. Non-metallic mineral products } \\
\text { 9. Metal products } \\
\text { 10. Machinery } \\
\text { 11. Transport equipment } \\
\text { 12. Electronic products } \\
\text { 13. Other manufacturing products } \\
\text { 14. Electricity, gas and water supply }\end{array}$ & 2. Manufacturing & $\begin{array}{l}\text { 2. Mining } \\
\text { 3. Manufacturing } \\
\text { 4. Supply of electricity, gas and water }\end{array}$ \\
\hline 3. Construction (CON) & 6. Construction & 15. Construction & 4. Construction & 5. Construction \\
\hline $\begin{array}{l}\text { 4. Trade and Transport } \\
\text { (TRA) }\end{array}$ & $\begin{array}{l}\text { 7. Transportation, post and } \\
\text { communication services } \\
\text { 8. Commerce and catering } \\
\text { services }\end{array}$ & 16. Trade and transport & $\begin{array}{l}\text { 5. Transport, post and } \\
\text { telecommunications } \\
\text { 6. Commerce,, catering services and } \\
\text { wholesale and retail trade }\end{array}$ & $\begin{array}{l}\text { 7. Transport, storage, post and } \\
\text { telecommunications } \\
8 \text {. Wholesale and retail trade and } \\
\text { catering services }\end{array}$ \\
\hline $\begin{array}{l}\text { 5. Service } \\
\text { (SER) }\end{array}$ & 9. Non-material industries & 17. Services & $\begin{array}{l}\text { 3. Geological prospecting } \\
\text { 7. Real estate, public utility, resident } \\
\text { service and consulting service } \\
\text { 8. Health care, sports and social welfare } \\
\text { 9. Education, culture and art, radio, film } \\
\text { and television } \\
\text { 10. Scientific research and } \\
\text { polytechnical services } \\
\text { 11. Banking and insurance } \\
\text { 12. Government agencies, party } \\
\text { agencies and social organizations } \\
\text { 13. Others }\end{array}$ & $\begin{array}{l}\text { 6. Geological prospecting and water } \\
\text { conservancy } \\
\text { 9. Banking and insurance } \\
\text { 10. Real estate trade } \\
\text { 11. Social services } \\
\text { 12. Health care, sports and social } \\
\text { welfare } \\
\text { 13. Education, culture and art, radio, } \\
\text { film and television } \\
\text { 14. Scientific research and } \\
\text { polytechnical services } \\
\text { 15. Government agencies, party } \\
\text { agencies and social organizations } \\
\text { 16. Others }\end{array}$ \\
\hline
\end{tabular}


Table 3. Summary Statistics on Labor Productivity by Sector (in 1987 RMB per employee)

\begin{tabular}{|c|c|c|c|c|c|c|c|c|c|c|c|c|c|c|c|c|c|c|}
\hline & & & 1987 & & & & & & & & 1997 & & & & & & & \\
\hline Sector & Mean & $\begin{array}{l}\text { Standard } \\
\text { Deviation }\end{array}$ & $\begin{array}{l}\text { Dispersion } \\
\text { coefficient }\end{array}$ & Max. & Region & Share $^{1}$ & Min. & Region & Share & Mean & $\begin{array}{l}\text { Standard } \\
\text { Deviation }\end{array}$ & $\begin{array}{l}\text { Dispersion } \\
\text { coefficient }\end{array}$ & Max. & Region & Share & Min. & Region & Share \\
\hline AGR & 1,116 & 310 & 27.78 & 1,647 & $\mathrm{NE}$ & 8.36 & 644 & SW & 16.25 & 2,006 & 688 & 34.30 & 2,895 & $\mathrm{NE}$ & 5.65 & 1,160 & SW & 26 \\
\hline MAN & 4,926 & 523 & 10.62 & 5,768 & $\mathrm{NE}$ & 16.08 & 4,327 & $\mathrm{CC}$ & 19.47 & 1,0731 & 3,089 & 28.79 & 15,235 & $\mathrm{SC}$ & 10.25 & 7,488 & $\mathrm{CC}$ & 24.27 \\
\hline $\mathrm{CON}$ & 2,819 & 444 & 15.75 & 3,806 & $\mathrm{NE}$ & 13.64 & 2,422 & $\mathrm{CC}$ & 21 & 5,673 & 1,651 & 29.11 & 7559 & $\mathrm{SC}$ & 11.04 & 3,320 & $\mathrm{CC}$ & 26.63 \\
\hline TRA & 3,288 & 529 & 16.09 & 4,270 & $\mathrm{EC}$ & 17.98 & 2,627 & $\mathrm{CC}$ & 20.84 & 3,285 & 1,069 & 32.54 & 4935 & $\mathrm{EC}$ & 12.89 & 1,866 & $\mathrm{CC}$ & 27.76 \\
\hline SER & 2,933 & 413 & 14.08 & 3,846 & $\mathrm{NE}$ & 12.68 & 2,535 & SW & 13.09 & 6,461 & 2,807 & 43.45 & 10,114 & $\mathrm{NC}$ & 13.91 & 3,492 & SW & 19.43 \\
\hline
\end{tabular}

Note: Share means the employment share of the sector with the maximum or minimum labor productivity in its corresponding (maximum or minimum) region.

Table 4. Labor Productivity Levels (in 1987 RM per Employee) and Annualized Growth Rate (percent) by Region

\begin{tabular}{lrrr}
\hline \hline Region & 1987 & 1997 & $\begin{array}{r}\text { Annualized } \\
\text { Growth Rate }\end{array}$ \\
\hline NE & $3,492.13$ & $5,000.01$ & 3.65 \\
NC & $2,489.05$ & $5,473.01$ & 8.20 \\
EC & $3,023.54$ & $7,425.38$ & 9.40 \\
SC & $2,239.29$ & $6,688.80$ & 11.56 \\
CC & $1,771.94$ & $2,702.89$ & 4.31 \\
NW & $1,887.71$ & $3,263.19$ & 5.63 \\
SW & $1,332.61$ & $2,455.71$ & 6.30 \\
China & $2,142.89$ & $4,174.60$ & 6.90 \\
\hline \hline
\end{tabular}

Southern Regional Science Association 2010. 
Figure 2. China's Labor Productivity Growth by Region and Sector, 1987-1997

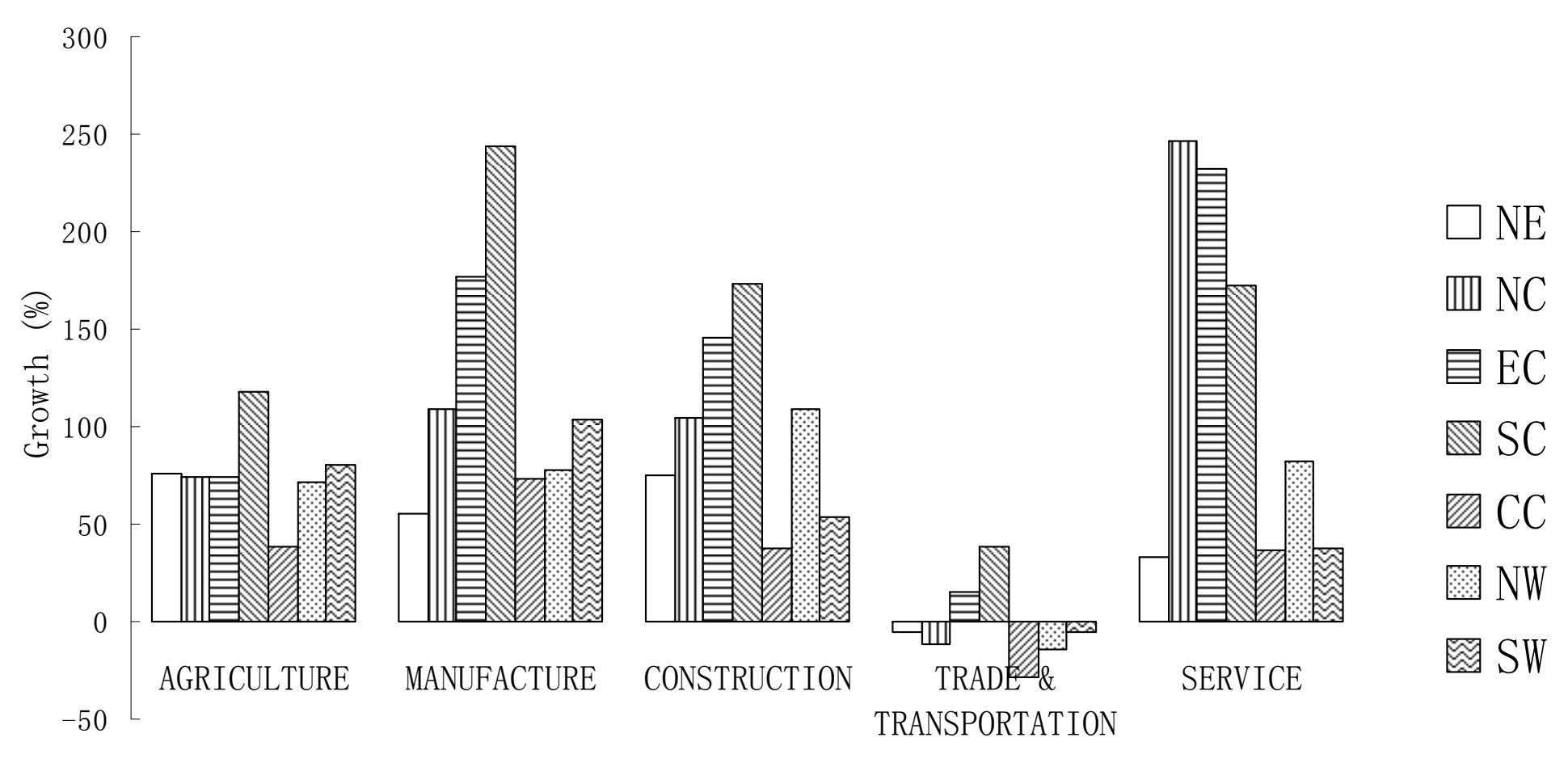

Sector 
Transportation ranked second, third, and fourth, respectively. This shows the basic transition in China's economic development during the period toward Services.

We use the dispersion coefficient (standard deviation divided by the mean) to enable comparisons in the productivity across regions. We find that Agriculture's productivity varied most across the seven regions in both 1987 and 1997. This is unsurprising since a basic criterion for regional definitions used in the MRIOs was the geography of Agriculture, which relies on natural endowments. All five sectors have demonstrated an increase in this measure for productivity from 1987 to 1997. This indicates that China has experienced increasing productivity disparity among regions even within these major sectors.

During the study period, China's economy experienced rapid growth as the fully centrally planned economy transformed into more of a market economy. The path of labor productivity's part in this transformation differed significantly across regions. Among the seven regions in 1987, Northeast China was consistently among the most productive regions for almost every one of the five sectors. By 1997, however, South and North China had made sufficient progress to surpass Northeast China in one or two of them. East China had the highest labor productivity for the Trade and Transportation sector in both years. This general spatial pattern of high productivity undoubtedly reflects China's focus on economic development along its eastern seaboard. As we know, some preferential policies had been implemented for the Coast by 1997. We should also note that the high dispersion of labor productivity levels within the same sector among regions is likely due to the very different mix of industries below the sector level used in our analysis, rather than to a high variation in labor productivity levels of uniform products. Given the high level of aggregation in the MRIO tables, we often had to remind ourselves of this fact, particularly when analyzing results for the Manufacturing and Service sectors. Both are aggregates of a large number of heterogeneous industries. Also, in the course of the analysis we recalled the sage advice of Dietzenbacher, Hoen, and Los (2000): that sectors with the highest productivity levels ought not to be automatically interpreted as being the most technologically advanced. This is because labor productivity levels are also affected by capital-labor ratios that partly depend upon relative factor prices. Thus, we often found that the employment share of the sector with the lowest labor productivity level among the five sectors was greater than the one with highest labor productivity. This implies that labor productivity can increase with regional specialization, which causes the demand for labor to decrease.

Table 4 presents summary statistics for the seven regions in China from 1987 to 1997. Central China, Southwest China, and Northwest China, which start out with low initial labor productivity endowments, have relatively low productivity growth during the ten following years. In contrast, the other three regions including North China, East China, and South China develop with surprising speed. The Northeast, as we can observe from Table 3, maintains a relatively low growth rate throughout the period, despite a higher initial labor productivity endowment.

From Figure 2 we can see that almost all sectors in every region experienced positive labor productivity growth rates during the study period. An exception is Trade and Transportation. Labor productivity for that sector actually decreased across five of the regions during the study period. The reason for this may be manifold. First, it can probably be attributed to inaccuracies in China's statistical system. Hioki and Okamoto (2009) point out some problems with China's statistical information system for the transportation industry; in particular, they focus on the inconsistency between transportation statistics and other national economic statistics. Second, the Trade and Transport sector itself in general does not appear to produce high amounts 
of value added per unit of production compared with the other four sectors. Also, since data on total hours worked by sector were not available, the employment data we use represents the total number of workers engaged in the industry including temporary employees. Thus, the issue could be more fundamental; that is, it may well be that, as elsewhere in the world, the sector experienced a rapid increase in its use of part-time and seasonal employees. This would, of course, lead to some bias in our analysis - bias that we cannot account for due to data limitations in China.

For North China, the Service sector is of vital importance. Its share increased from 13.7 percent in 1987 to 26.3 percent in 1997, making it the region's second largest sector in 1997. Although several other sectors also demonstrated a strong performance, the Service sector was notable in that it experienced an increase in its labor productivity growth of more than 100 percent during the period of study. All sectors in East China performed above average, and the region especially excelled in Services, Manufacturing, and Construction. South China owes most of its aggregate productivity increase to Manufacturing, but Construction and Service also contributed. In Central China things appear to be far less sanguine, with almost all sectors lagging behind those in other regions. The growth in the Northwest can largely be attributed to Construction, as its labor productivity ranks top among all sectors in this region. This can probably be attributed to the national government's West Development Strategy. The Southwest performed best in Manufacturing, and sectors in the Northeast did not show much change.

To this point, we attempted to relate a general understanding about temporal and spatial variations in China's labor productivity from 1987 to 1997. Both labor productivity and its growth rate differ across regions and industries. But we have not yet ascertained what contributed to the total change. The following decomposition analysis is our attempt to make this determination.

\subsection{Decomposition results}

The results of the application of decomposition for Equations (1) and (2) are reported in Tables 5 and 6 . Table 5 displays the perspective of regions by aggregating sectors, and Table 6 focuses on sectors by aggregating regions.

Based on the MRIO data, labor productivity in China increased by 94.8 percent during the 1987-1997 period - an annualized average growth rate of 6.9 percent. The increase was mainly caused by a decrease in labor used per unit of gross output. This alone accounts for an increase in productivity of 100.7 percent (the geometric average of the two decompositions). This effect was partly offset by a shrinking of value added's share of total output - a reduction of about 18 percent.

The decrease of labor input per unit of gross output indicates the adoption of labor-saving processes, which resulted in the substitution of capital for labor or reductions in disguised unemployment. Much of the change was undoubtedly induced via market pressures as China engaged more fully in the world marketplace as suggested by Tybout (1992), among others. China's reform started in 1978, and in 1992 China's government proposed its current socialist market economy. During the transition, in July 1986, the government issued a regulation that state-owned enterprises could hire via contracts. This meant that such enterprises could not only hire but also fire personnel. In 1995, the labor contract system was implemented comprehensively. But it was not until 1998 that the government definitely proposed that 
Table 5. Labor Productivity Decomposition Results by Region

\begin{tabular}{lllllllllllllllll}
\hline \hline Region & Total $^{1}$ & \multicolumn{3}{c}{ Factor 1 $^{2}$} & \multicolumn{3}{c}{ Factor 2 } & \multicolumn{3}{c}{ Factor 3 } & \multicolumn{3}{c}{ Factor 4 } \\
NE & 1.432 & 0.755 & 0.782 & 0.769 & 1.927 & 1.877 & 1.902 & 1.027 & 0.994 & 1.010 & 0.952 & 0.975 & 0.963 & 1.005 & 1.007 & 1.006 \\
NC & 2.199 & 0.825 & 0.811 & 0.818 & 2.410 & 2.224 & 2.315 & 1.021 & 1.071 & 1.046 & 1.028 & 1.028 & 1.028 & 1.054 & 1.108 & 1.081 \\
EC & 2.456 & 0.787 & 0.797 & 0.792 & 2.809 & 2.459 & 2.628 & 1.071 & 1.156 & 1.112 & 0.974 & 0.955 & 0.964 & 1.065 & 1.135 & 1.100 \\
SC & 2.987 & 0.823 & 0.857 & 0.840 & 2.935 & 2.572 & 2.747 & 1.057 & 1.091 & 1.074 & 1.036 & 1.059 & 1.048 & 1.129 & 1.172 & 1.150 \\
CC & 1.525 & 0.847 & 0.850 & 0.848 & 1.597 & 1.559 & 1.578 & 1.066 & 1.064 & 1.065 & 1.028 & 1.020 & 1.024 & 1.029 & 1.061 & 1.044 \\
NW & 1.729 & 0.870 & 0.872 & 0.871 & 1.903 & 1.873 & 1.888 & 1.006 & 1.011 & 1.009 & 0.974 & 0.980 & 0.977 & 1.065 & 1.070 & 1.067 \\
SW & 1.843 & 0.843 & 0.856 & 0.849 & 1.919 & 1.905 & 1.911 & 1.091 & 1.081 & 1.086 & 0.972 & 0.975 & 0.973 & 1.075 & 1.073 & 1.074 \\
China & 1.948 & 0.818 & 0.827 & 0.823 & 2.090 & 1.928 & 2.007 & 1.066 & 1.086 & 1.076 & 0.998 & 0.997 & 0.998 & 1.071 & 1.128 & 1.099 \\
\hline \hline
\end{tabular}

Notes: Ratio of labor productivity in 1997 to that in 1987; First columns of each factor refer to results of Equation (1) and second columns refer to results of Equation (2) and third columns refer to Fisher indexes, which is the geometric average of the first two indexes.

\section{Table 6. Labor Productivity Decomposition Results by Sector}

\begin{tabular}{|c|c|c|c|c|c|c|c|c|c|c|c|c|c|c|c|c|}
\hline \multirow{2}{*}{$\begin{array}{l}\text { Industry } \\
\text { AGR }\end{array}$} & \multirow{2}{*}{$\frac{\text { Total }^{1}}{1.668}$} & \multicolumn{3}{|c|}{$\begin{array}{l}\text { Factor } 1^{2} \\
\text { (value added per unit } \\
\text { of gross output) }\end{array}$} & \multicolumn{3}{|c|}{$\begin{array}{c}\text { Factor } 2 \\
\text { (labor input per unit } \\
\text { of gross output) }\end{array}$} & \multicolumn{3}{|c|}{$\begin{array}{c}\text { Factor } 3 \\
\text { (input structure) }\end{array}$} & \multicolumn{3}{|c|}{$\begin{array}{c}\text { Factor } 4 \\
\text { (interregional trade } \\
\text { of intermed. inputs) }\end{array}$} & \multicolumn{3}{|c|}{$\begin{array}{c}\text { Factor } 5 \\
\text { (final demand) }\end{array}$} \\
\hline & & 0.867 & 0.864 & 0.866 & 1.929 & 1.912 & 1.920 & 0.998 & 1.000 & 0.999 & 1.001 & 1.000 & 1.000 & 0.999 & 1.010 & 1.004 \\
\hline MAN & 2.142 & 0.790 & 0.791 & 0.790 & 2.786 & 2.645 & 2.715 & 0.982 & 0.981 & 0.981 & 0.995 & 0.998 & 0.996 & 0.997 & 1.047 & 1.021 \\
\hline $\mathrm{CON}$ & 1.892 & 0.942 & 0.947 & 0.945 & 2.010 & 1.905 & 1.957 & 0.998 & 1.000 & 0.999 & 1.000 & 1.000 & 1.000 & 1.001 & 1.049 & 1.025 \\
\hline TRA & 0.950 & 0.832 & 0.832 & 0.832 & 1.125 & 1.092 & 1.108 & 1.005 & 1.001 & 1.003 & 0.996 & 0.994 & 0.995 & 1.013 & 1.052 & 1.032 \\
\hline SER & 2.072 & 0.795 & 0.803 & 0.799 & 2.587 & 2.299 & 2.439 & 0.996 & 1.055 & 1.025 & 1.000 & 0.997 & 0.998 & 1.012 & 1.068 & 1.039 \\
\hline
\end{tabular}

Notes: Ratio of labor productivity in 1997 to that in 1987; First columns of each factor refer to results of Equation (1) and second columns refer to results of Equation (2) and third columns refer to Fisher indexes, which is the geometric average of the first two indexes. 
employment be open to the full force of the market economy without government intervention. Our study period from 1987 to 1997 strictly covers the period of employment transition to a market-oriented system. Therefore, the large labor saving effect is not especially odd for the coastal regions, where the reformation first took place.

Although not directly detectable from the results in Table 5, we should note that the length of the work week was substantially reduced in 1994 and again in 1995. Prior to March 1, 1994, the work week was a mandated 48 hours long; from that date on, it was reduced to 44 hours. The official work week was reduced further by 4 hours to 40 hours starting on May 1 , 1995. This means that if one is really interested in measures of labor productivity growth and labor input per unit of gross output that are based on a labor-hours rather than a job basis, the numbers in Table 5 and Table 6 are clear underestimates. Unfortunately, the figures do not distinguish part-time labor and full-time labor, and thus it may also lead to underestimates according to China's existing statistical system.

We should note that value added per unit of gross output was, in many cases, also caused by the same labor-saving effect as well as being laid open to the ravages of pressures from increasing exposure to world markets. In particular, the latter undoubtedly induced tax and profit shares in China to decrease by about 5 percent between 1987 and 1997. Changes in input structure (factor 3) and in final demand (factor 5) have a net positive effect on the growth of labor productivity. While changes in interregional trade (factor 4) seem to have yielded no contribution to the labor productivity at the national level, change in final demand provided a greater impetus for labor productivity growth than did change in intermediate input structurei.e., change in technology and in the mix of industries within each sector.

The findings summarized for each of the seven regions are quite similar to those for China as a whole. Decreased labor input per unit of gross output contributes the most to labor productivity growth, followed by changes in final demand. Input structure tends to rank after these two as a key factor. Reduction in the ratios of value added per unit of gross output markedly dampened the labor productivity increases.

Our results differ quite a bit from those of Dietzenbacher, Hoen, and Los (2000) in that they found the effects from both changes in intermediate structure and trade and changes in final demand had no perceptible effect on growth of labor productivity for any of the Euro- 6 countries they analyzed. While our findings for change in interregional trade were similar, those for final demand were not. Indeed, change in final demand nearly consistently contributed substantially to labor productivity growth in each of the seven regions and five industries in the MRIO tables we used to analyze China's economy. Thus, in our case both the change in the structure of final demand and of intermediate input appear to have fostered growth in labor productivity in China from 1987 to 1997.

We also found that value-added's share of gross output reduced its contribution to labor productivity growth by about 18 percent for each of China's regions. Dietzenbacher, Hoen, and Los (2000) found a less dramatic 10 percent reduction in this factor's contribution to labor productivity growth. The difference is undoubtedly due to the establishment of a market economy and the world's openness to rapidly increasing trade with China. While the Euro-6 also benefited from a greater openness in trade during the study period employed by Dietzenbacher, Hoen, and Los (2000), those countries were already among the world's leaders in adopting technological innovations and engaged heavily in international trade prior to the study period. 
Hence, the economic pressures of freer trade were not nearly so heavily felt in Europe between 1975 and 1985 as they were in China between 1987 and 1997.

When we look at the factors by region, it can be inferred that the high labor productivity growth in North China, East China, and South China derives largely from large decreases in the use of labor per unit of gross output. Except in the Northeast and Northwest, changes in input structure improved labor productivity, particularly in East China, where the effect was over 11 percent. Interregional trade had a clear positive effect on North China, South China, and Central China-about 2.8, 4.8, and 2.4 percent, respectively. But it had negative effects on Northeast, East China, Northwest, and Southwest—about 3, 4, 3, and 3 percent, respectively.

We made several cursory investigations in attempts to explain why the interregional trade effects were positive for some regions while negative for others. Unfortunately, each approach only supported a subset of the regions. In one approach we examined each region's in-and outflows with imports calculated from the perspectives of both using and producing industries. Analyses of these data revealed that Manufacturing was by far the dominant trading sector for all regions in both periods. We also compare the change in labor productivity of in- and outflows (calculated for using industries using a weighted average) for the sectors by region. We hypothesized that those regions' sectors with higher labor productivities for their outflows than their inflows should yield positive effects on labor productivity and, of course, that the opposite should yield negative productivity effects. This proved to be the case for five of the seven regions: East China and Central China were anomalies. We also calculate each sector's outflow share by region with the hypothesis that interregional trade effects would be positive when the outflow's share in high-productivity sectors increases between 1987 and 1997. Again, for all but East China the hypothesis appeared to be valid. Thus despite the modicum of success our search for explanations of the results obtained, it is clear that some further research is required in order to ascertain more precisely what factors contributed to the interregional trade effects we observed.

Factor 5, change in final demand, has a major effect on all the regions but the Northeast. We found that, from 1987 to 1997, the Northeast's final demand share in Trade and Transportation increased from 1.6 percent to 7.4 percent. As we mentioned above, labor productivity of this sector was low and decreased during the period. This may well be a major reason that the effect of final demand is less important in Northeast.

From Table 6, observe that labor productivity increased by an astounding 114 percent from 1987 to 1997 in Manufacturing and 107 percent in the Service sector. At the same time, as stated earlier, productivity in Trade and Transportation declined. Most sectors in China experienced larger rises in labor productivity and drops in value-added per unit of gross output from 1987 to 1997 than did their counterparts in the Euro-6 between 1975 and 1985. Again, labor productivity improvements for each of the sectors derive mainly from declines in labor input per unit of gross output. Skyrocketing labor productivity in the Manufacturing and Service sectors are largely caused by this. The second most important factor across the sectors is the change in value added per unit of output. It is negative, however, and hence dampened productivity growth.

As has been the story throughout this paper, changes in the structure of inputs and final demand had smaller effects compared with the first two factors. Their magnitudes are nonetheless significantly larger than the corresponding factors for the Euro- 6 countries during 
the 1975-1985 period, as estimated by Dietzenbacher, Hoen, and Los (2000). The effects of input structure are negligible for almost all of the sectors except Service, and the final demand factor comprised between 2.1 to 3.9 percent of the change across all sectors but Agriculture. Changes in the pattern of interregional trade had almost no effect on the productivity of the sectors; there may be some explanations for this. The Construction and Service sectors do not generally produce traded goods or services. Dietzenbacher, Hoen, and Los (2000) elaborate on this. Compared to other sectors, change in the structure of final demand for the Service sector contributed most to overall sectoral productivity growth, and at 2.9 percent its change in input structure also yielded relatively large effects compared to other sectors.

Comparing Table 5 to Table 6, we can make further inferences. The first two factors tend to yield the largest effects, while effects from the last three factors tend to be smaller. The lack of effect from changes in input structure is readily explained by the generally slow pace of technology change within a ten-year timeframe. Work by Carter (1970), Blair and Wyckoff (1989), and Shishido et al. (2000) suggests that ten years is insufficiently long to change average industry structure much even in innovative industries. ${ }^{5}$ That these factors have more effect upon regions than upon sectors implies that different intrasectoral structures exist across the regions and, thus, that subsector mix issues generate some substantial share of the regional disparity in labor productivity.

Throughout the paper we have compared our results for China with those by Dietzenbacher, Hoen, and Los (2000) for the Euro-6 countries. Doing so gives us some measure for comparison and enlightens us about the relative magnitude of labor productivity growth as well as providing some background for identifying further causes of interregional disparities in productivity growth. In summary, we have found that all factors tended to provide greater impetus for labor productivity growth in China between 1987 and 1997 than they did in Euro-6 countries from 1975 to 1985 . We believe that Chinese economic reform and the transformation from a planned economy to a market economy are the main forces. In addition because centralized collection of regional data is a relatively new activity in China technical errors inherent in the data may abound, including the different ways in which the two Chinese multiregional I-O tables were built.

Dietzenbacher, Hoen, and Los (2000) note that the I-O tables they used were constructed using exchange rates among the countries rather than purchasing power parity (PPP) conversions. Since our analysis focuses on regions of a single country, PPP versus exchange-rate conversion is a non-issue. For similar reasons, transaction costs of trade among regions of a single country are naturally smaller than they are for trade among different countries. That is, outside of transportation costs, the flow of commodities and services should be relatively frictionless for China, which is not the case for the Euro-6. Thus, China's economic reformation, which started in 1978, was better able to induce sweeping technology change during the second decade following that reform than could the European Union. Most studies of technology change have been undertaken in relatively stable economies or in economies in decades when trade and information exchange were slower on the uptake.

\footnotetext{
${ }^{5}$ See Chapter 7 and the initial sections of Chapter 13 and 14 of Miller and Blair (2009) for additional details.
} 


\section{CONCLUSIONS}

Few papers have studied the factors contributing to changes in labor productivity with multiregional input-output tables. This is particularly the case for China. In this paper we use two multiregional input-output tables and disaggregated employment data to examine change in labor productivity growth for seven regions and five sectors of the Chinese economy between 1987 and 1997. We decompose the potential causes of change in labor productivity into five partial effects. We find that the increase of labor productivity for regions and sectors in China mainly comes from the decreasing labor input per unit of gross output and from changes in value added's share of gross output. Aggregate production mix, interregional trade, and final demand also have important but smaller effects on most of regions and their sectors in China.

We found that the factor effects were larger by region than by industry. This suggests that regions' subsector industry mixes also play a major role in causing interregional disparities in labor productivity. The paper also shows that all the factors displayed larger effects in China from 1987 to 1997 than they did for Euro-6 countries from 1975 to 1985.

Like other decomposition methods, this approach deals only with proximate causality, and thus we give our understanding based on the knowledge of institutions, history, policy, and so on. Due to relatively poor economic statistical reporting, especially for the early years, we can only present a rather aggregate decomposition of China's labor productivity among regions and sectors. There may be some bias in our analysis, due to employment data limitations which forced us to use job-years instead of hours worked. Accordingly, more detailed insight is not really possible. Nonetheless, our analysis presents a fresh perspective on an issue of national and possibly even international interest. We therefore hope our work induces others to make further investigations into China's interregional disparities in labor productivity when higher quality data are readily available.

\section{REFERENCES}

Blair, Peter D. and Andrew W. Wyckoff. (1989) "The Changing Structure of the U.S. Economy: An Input-Output Analysis," in Ronald E. Miller, Karen R. Polenske, and Adam Z. Rose, eds., Frontiers of Input-Output Analysis. Oxford University Press: New York, pp. 293307.

Carter, Anne P. (1970) Structural Change in the American Economy. Harvard University Press: Cambridge, MA.

Cai, Fang, Dewen Wang, and Yang Du. (2002) "Regional Disparity and Economic Growth in China: The Impact of Labor Market Distortions," China Economic Review, 13, 197-212.

China's State information Center. (2005) Multi-regional Input-Output Table for China. Social Science Academic Press: Beijing.

Démurger, Sylvie. (2001) "Infrastructure Development and Economic Growth: An Explanation for Regional Disparities in China?" Journal of Comparative Economics, 29, 95-117.

Démurger, Sylvie, Jeffrey. D. Sachs, Wing T. Woo, Shuming Bao, Gene Chang, and Andrew Mellinger. (2002a) "Geography, Economic Policy and Regional Development in China," Asian Economic Papers, 1, 146-197.

Southern Regional Science Association 2010. 
Démurger, Sylvie, Jeffrey. D. Sachs, Wing T. Woo, Shuming Bao, and Gene Chang. (2002b) "The Relative Contributions of Location and Preferential Policies in China's Regional Development: Being in the Right Place and Having the Right Incentives," China Economic Review, 13, 444-465.

Dietzenbacher, Erik, Alex R. Hoen, and Bart Los. (2000) "Labor Productivity in Western Europe 1975-1985: An Intercountry, Interindustry Analysis," Journal of Regional Science, 40, $425-452$.

Dietzenbacher, Erik and Alex R. Hoen. (1998) "Deflation of Input-output Tables from the User's Point of View: A Heuristic Approach,” Review of Income and Wealth, 44, 111-122.

Hioki, Shiro, Geoffrey J. D. Hewings, and Nobuhiro Okamoto. (2009) "Identifying the Structural Change of China's Spatial Production Linkages Using a Qualitative input-Output Analysis," Journal of Econometric Study of Northeast Asia, 6, 25-48.

Hioki, Shiro and Nobuhiro Okamoto. (2009) "How Have China's Intra- and Inter-regional InputOutput Linkages Changed during the Economic Reform," in Nazrul Islam, ed., Resurgent China: Issues for the Future. Palgrave MacMillan: London, pp. 181-212.

Ichimura, Shinichi and Hui-Jiong Wang. (2003) Interregional Input-Output Analysis of the Chinese Economy. World Scientific Publishing Co. Inc.: Singapore.

Kanbur, Ravi and Xiaobo Zhang. (2005) "Fifty Years of Regional Inequality in China: A Journey through Revolution, Reform and Openness," Review of Development Economics, 9, 87-106.

Li, Huaqun and Kingsley E. Haynes. (2008) "Industrial Structure and Regional Disparity in China: Beyond the Kuznets Transition" 47th Southern Regional Science Association Annual Meeting in Washington, DC.

Lin, Justin Yifu and Peilin Liu. (2008) "Development Strategies and Regional Income Disparities in China," in Guanghua Wan, ed., Inequality and Growth in Modern China. Oxford University Press: New York, pp. 56-78.

Liu, Tung and Kui-Wai Li. (2006) "Disparity in Factor Contributions between Coastal and Inner Provinces in Post-reform China," China Economic Review, 17, 449-470.

Meng, Bo and Chao Qu. (2007) "Application of the Input-Output Decomposition Technique to China's Regional Economies,” IDE Discussion Papers, No.102, available March 2009 at http://ir.ide.go.jp/dspace/bitstream/2344/552/1/ARRIDE_Discussion_No.102_meng.pdf

Miller, Ronald E. and Peter D. Blair. (2009) Input-Output Analysis: Foundations and Extensions, $2^{\text {nd }}$ edition. Cambridge University Press: New York.

National Bureau of Statistics of China. (1988-1998, 2008) China Statistical Yearbook. China Statistics Press: Beijing.

- (1988-1990) China Industry Economy Statistical Yearbook. China Statistics Press: Beijing.

. (2006)China Urban Life and Price Yearbook. China Statistics Press: Beijing. . (1949-2004). China Statistical Data Compilation, 2005. China Statistics Press: Beijing.

Southern Regional Science Association 2010. 
Shishido, Shuntaro, Makoto Nobukuni, Kazumi Kawamura, Takahiro Akita, and Shunichi Furukawa. (2000) "An International Comparison of Leontief Input-Output Coefficients and its Application to Structural Growth Patterns," Economic Systems Research, 12, 4564.

Sun, Haishun and Ashok Parikh. (2001) "Exports, Inward Foreign Direct Investment (FDI) and Regional Economic Growth in China," Regional Studies, 35, 187-196.

Tybout, James R. (1992) "Linking Trade and Productivity: New Research Directions," World Bank Economic Review, 6, 189-211.

Wei, Shang Jin and Wu Yi. (2001) "Globalization and Inequality: Evidence from within China," NBER Working Paper 8611.

Wei, Yehua Dennis. (2000) "Investment and Regional Development in Post-Mao China," Geojournal, 51, 169-179.

Yang, Dennis Tao. (2002) “What Has Caused Regional Inequality in China?” China Economic Review, 13, 331-334. 


\section{APPENDIX}

Table of Data Used to Produce Price Indices

\begin{tabular}{|c|c|c|c|}
\hline No. & Sector & Price index calculation & Remark \\
\hline 1 & Agriculture & $\begin{array}{l}\text { Product of year-by-year agriculture product } \\
\text { producer price index }\end{array}$ & $\begin{array}{l}\text { Data from the website of Ministry of Agriculture of the People's Republic } \\
\text { of China http://www.agri.gov.cn/sjzl/baipsh/WB2007.htm\#26 }\end{array}$ \\
\hline 2 & Mining & Product of year-by-year mining index & $\begin{array}{l}\text { Index from "ex-factory price indices of industrial products" in } 2006 \text { China } \\
\text { urban life and price yearbook }\end{array}$ \\
\hline 3 & Food products & Product of year-by-year food index & $\begin{array}{l}\text { Index from "ex-factory price indices of industrial products by sector" in } \\
2006 \text { China urban life and price yearbook }\end{array}$ \\
\hline 4 & $\begin{array}{l}\text { Textile and wearing } \\
\text { apparel }\end{array}$ & $\begin{array}{l}\text { Weighted average of price index from } 3 \\
\text { constituent industries, which are textile goods, } \\
\text { wearing apparel, leather, furs and related } \\
\text { products }\end{array}$ & $\begin{array}{l}\text { Index from "ex-factory price indices of industrial products by industry." } \\
\text { Weight is share of workers in different industries in base year and the data } \\
\text { come from China statistical yearbook for different years }\end{array}$ \\
\hline 5 & Wooden products & Product of year-by-year wooden index & $\begin{array}{l}\text { Index from "ex-factory price indices of industrial products by sector" } 2006 \\
\text { China urban life and price yearbook }\end{array}$ \\
\hline 6 & Paper and printing & $\begin{array}{l}\text { Products of year-by-year price index of paper } \\
\text { industry }\end{array}$ & $\begin{array}{l}\text { Index from "ex-factory price indices of industrial products by industry." } \\
\text { There is no printing index from China's database and it is probably } \\
\text { common sense that the index of printing is similar to that of the paper } \\
\text { industry, so we just use the price index of paper industry as that of the } \\
\text { sector. }\end{array}$ \\
\hline 7 & Chemical products & $\begin{array}{l}\text { Weighted average of the following } 6 \\
\text { industries: petroleum refining and coking, } \\
\text { chemical raw material and products, medical } \\
\text { and pharmaceutical products, chemical fibers, } \\
\text { rubber products and plastic products }\end{array}$ & Index from "ex-factory price indices of industrial products by industry." \\
\hline 8 & $\begin{array}{l}\text { Non-metallic mineral } \\
\text { products }\end{array}$ & Product of year-by-year index & Index from "ex-factory price indices of industrial products by sector" \\
\hline 9 & Metal products & $\begin{array}{l}\text { Weighted average of } 3 \text { industries: ferrous } \\
\text { metal processing, nonferrous metal processing } \\
\text { and metal products }\end{array}$ & Index from "ex-factory price indices of industrial products by industry." \\
\hline 10 & Machinery & $\begin{array}{l}\text { Products of year-by-year price index of } \\
\text { special machinery industry }\end{array}$ & $\begin{array}{l}\text { The machinery sector includes both the general and special machinery } \\
\text { industries, yet China only publishes the price index for special machinery; } \\
\text { we use it as a price index for the whole sector since we believe they are } \\
\text { almost the same based on our practical experience. }\end{array}$ \\
\hline 11 & Transportation equipment & Product of year-by-year index & Index from "ex-factory price indices of industrial products by industry" \\
\hline
\end{tabular}

Southern Regional Science Association 2010. 
Table of Data Used to Produce Price Indices (Cont)

\begin{tabular}{|c|c|c|c|}
\hline No. & Sector & Price index calculation & Remark \\
\hline 12 & Electronic products & $\begin{array}{l}\text { Weighted average of the electric equipment \& } \\
\text { machinery and electric \& telecommunication } \\
\text { equipments }\end{array}$ & $\begin{array}{l}\text { Workers data comes from } 2 \text { different sources: from } 1990 \text { to1996 from the } \\
\text { China statistical yearbook and from } 1987 \text { to } 1989 \text { from the China industry } \\
\text { economy yearbook because no detailed data is published in China statistical } \\
\text { yearbook in early years. We should note that these two kinds of data are not } \\
\text { quite consistent even for the same year and same industry; we believe } \\
\text { different statistical definitions have been used. But this will not lead to } \\
\text { mistakes in our analysis because we use percentage as a weight. }\end{array}$ \\
\hline 13 & $\begin{array}{l}\text { Other manufacturing } \\
\text { products }\end{array}$ & $\begin{array}{l}\text { Weighted average of instrument, meters, } \\
\text { culture \& office machinery industry and other } \\
\text { manufacturing products industry }\end{array}$ & Index from "ex-factory price indices of industrial products by industry" \\
\hline 14 & $\begin{array}{l}\text { Electricity, gas and water } \\
\text { supply }\end{array}$ & $\begin{array}{l}\text { Weighted average of electricity and water } \\
\text { industry }\end{array}$ & $\begin{array}{l}\text { Index from "ex-factory price indices of industrial products by industry". The } \\
\text { employment data for gas is only available from } 1993 \text { to } 1996 \text { because the data } \\
\text { before then is included in the industry of coking industry. The worker } \\
\text { percentage for gas industry of the whole sector from } 1993 \text { to } 1996 \text { is } 7.2,7.3 \text {, } \\
7.0 \text {, and } 6.6 \text { percent, respectively, which shows a weighted average of price } \\
\text { index from electricity industry and water industry is feasible. Though we } \\
\text { don't have the data for years from } 1986 \text { to } 1992 \text {, we can infer the percentage } \\
\text { will be no more than that for the latest four years because the volume of gas } \\
\text { supply in 1986-1992 mostly is less or equal to that in } 1993-1996 \text {. Given that } \\
\text { the technology for producing gas almost does not change, it is easy to prove } \\
\text { the worker percentage will be less or equal to } 7 \text { percent. }\end{array}$ \\
\hline 15 & Construction & $\begin{array}{l}\text { Product of year-by-year index of construction } \\
\text { material industry }\end{array}$ & Index from “ex-factory price indices of industrial products by sector” \\
\hline 16 & Trade and transport & $\begin{array}{l}\text { Weighted average of trade and transport } \\
\text { industry }\end{array}$ & Data is from China Statistical yearbook. \\
\hline 17 & Services & $\begin{array}{l}\text { a) Index for 1991-1997, weighted average of } \\
\text { all the industries } \\
\text { b) Index for } 1988-1990 \text {, we infer it with the } \\
\text { price index of the whole tertiary sector, the } \\
\text { trade industry and transport industry } \\
\text { c)Product of the year-by-year index }\end{array}$ & $\begin{array}{l}\text { a) Industries including geological prospecting and water conservancy, } \\
\text { banking and insurance, real estate trade, social services, health care, sports } \\
\text { and social welfare, education, culture and art, radio, film and television, } \\
\text { scientific research and polytechnic services, government agencies, party } \\
\text { agencies and social organizations and others. } \\
\text { b) China Statistical yearbook does not present GDP data for detailed } \\
\text { industries from } 1986 \text { to 1989, thus the method used in step 'a' can not be } \\
\text { adopted here. }\end{array}$ \\
\hline
\end{tabular}

Southern Regional Science Association 2010. 
The data we used to calculate the price index come from the website of the Ministry of Agriculture of the People's Republic of China, China Statistical Yearbook, the China Urban Life and Price Yearbook, and the China Industry Economy Yearbook. We were unable to find a proper price index for tertiary industries (both for the aggregate Service sector and its finer component industries) in the China Urban Life and Price Yearbook or other data bases for China. Nonetheless, we needed to calculate them using existing data. Thus we created an implicit GDP price deflator using data in the China Statistical Yearbook. We calculated it by taking the ratio of nominal GDP to real GDP for both 1987 and 1997, and dividing the 1997 result by the 1987 value.

For industries of the Manufacturing sector in the 1997 MRIO table, we selected the most appropriate price index from "ex-factory price indices of industrial products", "ex-factory price indices of industrial products by sector" and "ex-factory price indices of industrial products by industry" in the China Urban Life and Price Yearbook. (For the "ex-factory price indices of industrial products by sector," see the definition of the industry in the appendix to the 1988 China Industry Economy Yearbook.) Naturally, if an index was perfectly consistent with an industry in the 1997 MRIO table, we used it directly; otherwise, we generated a price index based on the weighting of several finer industries' indices. As weights we used the GDP share of tertiary industries. Due to the greater detail in the manufacturing industries and the lack of equivalently detailed GDP data, we used worker shares. We used base-year shares as weights.

Industrial reporting in China changed during the ten years that we study. For example, the foraging industry was a distinct industry before 1993: it was subsequently merged into the foodprocessing industry. Similarly, the coke-making industry was a distinct industry before 1990 and was subsequently merged into the petroleum-refining and coke-making industry. The industrial arts industry was included within the "other manufacturing" category prior to 1990 and was reported separately afterward. All of these anomalies were accounted for in as much as data permitted.

In several cases, we were forced to use a combination of data on manufacturing workers for both 1987 and 1988 from the China Statistical Yearbook as weights. We note that the 1989 China Statistical Yearbook reports 1988 industry data on workers only for establishments that were collectively owned. In 1988 about 98.8 percent of all Chinese manufacturing workers were employed by such organizations. Similarly, the 1988 China Statistical Yearbook reports worker counts by industry only for establishments collectively owned above the county level. In 1987 these organizations comprised more than 88.4 percent of all Chinese manufacturing workers. Despite this, our use of shares as weights should minimize any inherent bias, except in those industries especially sensitive to type of ownership.

Southern Regional Science Association 2010. 